$\begin{array}{lr}\text { Surnat Penelitian Pendidikan Bahasindonesia. } & \text { PRINTED ISSN: 2620-6919 } \\ \text { Daerah, dan Asing } & \text { ONLINE ISSN: 2620-3316 } \\ \text { Published by LP4MK STKIP PGRI LUBUKLINGGAU } & \text { Vol. 4, No. 1, JUne 2021 } \\ \begin{array}{l}\text { Prodi Pendidikan Bahasa Indonesia, STKIP PGRI Lubuklinggau, } \\ \text { South Sumatera, Indonesia }\end{array} & \text { Page: } 122-132\end{array}$

\title{
Illocutionary Acts Used in the Dead Poets Society Movie
}

\author{
Robiah AL Adawiyah \\ (corresponding author) \\ English Education Postgraduate Program, FKIP, University of Bengkulu \\ Email: robiahaladawiyah1403@yahoo.com \\ Irma Diani \\ English Education Postgraduate Program, FKIP, University of Bengkulu \\ Email: irmadianiunib@gmail.com \\ Azwandi \\ English Education Postgraduate Program, FKIP, University of Bengkulu \\ Email: azwandi22@gmail.com
}

\begin{abstract}
APA Citation: Adawiyah, R. A., Diani, I., \& Azwandi, A. (2021). Illocutionary acts used in the Dead Poets Society movie. Silampari Bisa: Jurnal Penelitian Pendidikan Bahasa Indonesia, Daerah, dan Asing, 4(1), 122-132. https://doi.org/10.31540/silamparibisa.v4i1.1175
\end{abstract}

\begin{abstract}
The purpose of this study was to describe the category of illocutionary and reaction to illocutionary interlocutors expressed by the speakers used in the Dead Poets Society movie. The method used in this study is a qualitative descriptive method. The object of the research is the Dead Poets Society movie script. Based on data analysis, the researcher found 72 utterances illocutionary acts, the dominant ones are Verdictives, namely Estimating and Behabitives, namely Complimenting, while the reaction of the interlocutor to illocutionary acts is dominated by Behabitives illocutionary acts, namely Applauding, and Expositives illocutionary acts, namely Denying. The researcher assumes the tendency of using inspired speech acts by the genre of movie, namely tragedy and drama because this movie features several characters show interest in poetry, and have conflicts between students, parents, and teachers when taught by Mr. Keating is considered to have deviated in principle from Welton Academy. The results of this study can be used as a reference in studying speech acts in pragmatics because, in this study, the researcher classified the types of illocutionary acts more easily based on Austin's theory.
\end{abstract}

Keywords: illocutionary act, Dead Poets Society movie

\section{Tindak Tutur Ilokusi yang Digunakan dalam Film Dead Poets Society}

\begin{abstract}
Abstrak
Tujuan penelitian ini adalah mendeskripsikan kategori ilokusi dan reaksi lawan bicara terhadap ilokusi yang diungkapkan oleh pembicara yang digunakan dalam film Dead Poets Society. Metode yang digunakan dalam penelitian ini adalah metode deskriptif kualitatif. Objek penelitiannya adalah naskah film Dead Poets Society. Berdasarkan analisis data, peneliti menemukan 72 tuturan ilokusi yang dominan adalah verdictives yaitu Estimating dan Behabitives yaitu Complimenting, sedangkan reaksi lawan bicara terhadap illokusi didominasi oleh illocutionary act Behabitives yaitu Applauding dan Expositives illocutionary
\end{abstract}


Robiah AL Adawiyah, Irma Diani, Azwandi

Illocutionary Acts Used in the Dead Poets Society Movie

act yaitu Denying. Peneliti berasumsi adanya kecenderungan penggunaan tindak tutur yang dipengaruhi oleh genre film yaitu tragedi dan drama karena film ini menampilkan beberapa tokoh yang menunjukkan ketertarikan terhadap puisi, juga menampilkan konflik antara siswa, orang tua, dan guru ketika yang diajarkan oleh Pak Keating dianggap telah menyimpang dari prinsip Akademi Welton. Hasil penelitian ini dapat dijadikan acuan dalam mempelajari tindak tutur pragmatik karena penelitian ini lebih mudah dimengerti dalam mengklasifikasikan jenis tindak ilokusi berdasarkan teori Austin.

Kata kunci: tindak tutur Ilokusi, film Dead Poets Society

\section{A. Introduction}

The main tools for communicating with each other are language. It is also possible to view language as a sign of sound that human beings use to carry out everyday life. It is important to deliver the dialogue that happens around us simply so that everyone can understand us (Wray \& Bloomer, 2006). It implies that someone needs to speak correctly so that the listener or the person who is talking to us will receive the message. A language used not only in oral communication but also in writing, e.g. in newspapers, journals, letters, and other forms, including manuscripts of numerous film or historical records (Noermanzah, 2019). We will learn other things from a film when we watch it. To learn more about the literary and pragmatic elements found in the films, we will acquire new information about schooling, values, actors' and actresses' acts, and the spoken language they use.

The investigator will examine speech acts from the movie. The smallest unit of language exchange is the speech acts. It is a branch of research into pragmatics. Pragmatics is distinguished from grammar, which is the study of the language's internal structure. Pragmatics is the study of how language is used to communicate (Parker, 1986:11). Meanwhile, Austin (1962:95) said that the speech act is the action that is performed by the speaker while saying something. In this analysis, the speech act is one of the key points of pragmatics. Learning speech acts will enable us to understand in each speech what signals have not been identified. People don't just make grammatical structures and words; they also use certain utterances to perform actions. Action performed via utterances are generally called speech act. (Yule,1996:47). Therefore, the relationship between pragmatics and speech acts is an utterance that can find meaning in which the speaker delivers it, and when we learn about pragmatics, speech acts are one of the significant studies (Mey, 2001).

Austin started with the study of speech acts. Not only do all the sentences identify or announce something (Austin, 1962:5). In his book titled "How to do Things with Words", Austin (1962:199) explained that in speech acts there are three components they are locutionary, illocutionary, and perlocutionary. A locutionary act is the real words of the speech, what the speaker means to express is an illocutionary act, and the response of the listener to the message of the speaker is perlocutionary actions (Faradila \& Hamzah, 2013). Too many researchers used Searle's theory in many articles and research papers that the researcher has read, so the researchers attempt to use Austin's theory as the guideline in this report.

The reason for concentrating on the study of speech acts is simply this; all linguistic communication involves linguistic acts (Afghari, 2007; Syafryadin et al., 2020). Speech acts are performed when people make utterances such as an apology, greeting, request, complaint, invitation, compliment, or refusal (Searle, 1979:16; Horn \& Ward, 2006). The speech acts are also decided by the language ability of the speaker to convey the message in communication (Leech, 1991). In Yule (1996) 
words, with pragmatics, people can talk about people's intended meanings, their assumptions, their purposes or goals, and the kinds of actions that they are performing when they are speaking. The movie script is a key item in the movie, in this case, study because it involves the spoken dialog script for characters in the movie (Maryam, 2020). The film script becomes the content of this analysis because every conversation to be researched offers a complete dialogue.

In addition, this movie's tendency to use speech acts is influenced by the genre of the movie, namely tragedy and drama, which features several characters who like poetry. Conflicts begin to emerge between students, parents, and a teacher, when taught by Mr. Keating, is considered to have deviated from Welton Academy principles. The movie also focuses on educational concerns as well. Education is viewed as a way of obtaining something which is material and status. Another thing that is also exposed in this film is that reforming an already developed structure is not easy in fact. This is demonstrated by Keating's inability to combat his school system, even though he was able to provide his students with a little perspective.

This research has some advantages for students who have the same research, in particular, the English Language Study Program, English teachers, and even potential researchers. The first advantage is for the student who will be a teacher after graduating from college in the English Language Education Study Program. The findings of this study will help them find an example of a suitable and good speech act that should be used in a classroom. In addition, the experience of linguistic aspects may also be enhanced by the student. The English teacher has the second advantage. The outcome of this research will ideally be an example of how to communicate an acceptable speech act to the student in the direction of an English teacher. In order to establish an active learning process for the situation of the class, the English teacher can follow the speech act that is based on this report. The last advantage is for future researchers who have the same analysis of the subject. Hopefully, this study will be used as a tool relevant to their research on speech acts.

To support this research, the researcher needs the other researches that have been made by other researchers that have a close relationship with the study. The first researcher is Sania (2018) from the University of Bengkulu. Her study is entitled An Analysis of Illocutionary Acts Used in Titanic Movie. Based on her research and this research is both of the research used the same theory and using a movie script as the object of research. But the differences are in object research. This research used Dead Poets Society as the object, and she used Titanic movie as the object research, then she only analyzes the illocutionary and perlocutionary aspect happen from the speaker while the researcher also analyzes the responses from the speakers. The second researcher is Putra (2017) from Sanata Dharma University Yogyakarta. Her study is entitled A Study of Mr. Keating's Speech Act in Dead Poet's Society Movie. Based on her research and this research, there are similarities found in this study, namely in the object section. These two studies use the same research object, and the differences can be seen in the theory used, where her research used Searle's theory as the method, while the researcher used Austin's theory to analyze the data.

The obvious difference between this analysis and the previously described research is the way this research is performed by the researcher. The researcher analyzes the illocutionary actions used by characters in the film Dead Poets Society in this analysis and discovers that the interlocutors react to the speakers' illocutionary powers. This study also aims to help the understanding students to analyze and 
categorize illocutionary ones. The reader can classify styles of speech actions easily based on the analysis. This outcome can be used as a reference so that especially linguistic more English Language Teaching is used.

\section{B. Research Methodology}

This research focuses on illocutionary acts from the movie based on Austin's theory so that this research used a descriptive qualitative method. The researcher used the Dead Poets Society movie as the object of the analysis to find out what kinds of illocutionary activities are based on Austin's theory. In order to provide a deep understanding of the story along with its meaning, the knowledge from this analysis is gathered by watching the film entitled Dead Poets Society and reading the script several times. The viewing process here works in the same way as synchronizing the original dialogs in the script with the dialogs spoken by the characters in the movie. Then, the researcher writes down the character's action description in the movie.

The instrument of this research is the researcher whose roles are planning, collecting, analyzing, and reporting and the datasheet is the second instrument to note the illocutionary act aspect which is needed in the research. The form of the datasheet is as follows:

Table 1. The Data Sheet of Classifying Types of Illocutionary Acts Used in Dead

Data Code:

$$
\text { Poets Society Movie }
$$

\begin{tabular}{|c|c|c|c|c|c|c|c|c|}
\hline \multirow{2}{*}{ No. } & \multirow{2}{*}{$\begin{array}{c}\text { Citation } \\
\text { Script }\end{array}$} & \multirow{2}{*}{ ACT } & \multicolumn{5}{|c|}{ Illocutionary Acts } & \multirow{2}{*}{ Situation } \\
\hline & & & Ver & Exe & Com & Beh & Exp & \\
\hline
\end{tabular}

Source: J.L. Austin 1962

$\begin{array}{llllll}\text { Note. Ver } & \text { : Verdictives } & \text { Exe } & \text { : Exercitives } & \mathrm{P} & \text { : Participant } \\ \text { Com } & : \text { Commisives } & \text { Beh } & \text { : Behabitives } & \mathrm{S} & \text { : Setting } \\ \text { Exp } & : \text { Expositives } & & & \mathrm{T} & \text { : Topic }\end{array}$

Table 2. The Datasheet of Classifying the Illocutionary Acts in Responses Shown by the Interlocutors

Data Code:

\begin{tabular}{llllllll}
\hline \multirow{2}{*}{\begin{tabular}{c} 
No. $\begin{array}{c}\text { Responses showed } \\
\text { by interlocutors }\end{array}$ \\
\cline { 3 - 7 }
\end{tabular}} & Act & \multicolumn{5}{c}{ Illocutionary Acts } \\
\cline { 3 - 7 } & & Ver & Exe & Com & Beh & Exp \\
\hline
\end{tabular}

\begin{tabular}{|c|c|c|}
\hline Note. & $\begin{array}{l}\text { Ver : Verdictives } \\
\text { Com: Commisives }\end{array}$ & $\begin{array}{l}\text { Exe } \\
\text { Beh }\end{array}$ \\
\hline
\end{tabular}

Exp : Expositives

To find the result, the data must be analyzed after the data collection is done. The data must also be given by means of qualitative and quantitative data. The formula was required to determine the percentage of the result in order to find the quantitative data. The formula was gathered from Arikunto (2014:81): 
Robiah AL Adawiyah, Irma Diani, Azwandi

Illocutionary Acts Used in the Dead Poets Society Movie

$$
\mathrm{P}=\frac{F}{N} \times 100 \%
$$

Source: Arikunto (2014:81)

Notes:

$\mathrm{P}=$ Percentage

$\mathrm{F}=$ Frequency of the text (Category Theme of culture)

$\mathrm{N}=$ some of texts

In analyzing the data, the researcher used both qualitative and quantitative techniques. The qualitative technique is mainly used considering the data which need to be described and interpreted in verbal form. Meanwhile, the quantitative technique is used to show the percentage of the data to support the data analysis. In this review, the researcher took some measures to gather information. The measures are as follows: the researcher explains and analyzes the selected utterances that include illocutionary actions used by the characters and finds the interlocutors' responses. Then, based on the data analysis, the researcher draws conclusions and recommendations. The information collected is illustrated in the datasheet. In the table below, the datasheet used by the researcher was presented.

Dialog 56

Mr. Nolan: In her first year, Welton Academy graduated five students. Last year we graduated fifty-one. And more than seventy-five percent of those went on to the Ivy League. This, this kind of accomplishment is the result of fervent dedication to the principles taught here. This is why you parents have been sending us here. This is why your parents have been sending us your sons. This is why we are the best preparatory school in the United States.

Mr. Nolan soaks up the applause from the audience.

The situation of the dialogue above is in the ceremony when Mr. Nolan delivers his speech in front of the students and their parents. Mr. Nolan's utterance contained reports of Welton Academy achievements from year to year, as well as the achievements of alumni who attend Welton Academy. Mr. Nolan action is category of Interpret in Verdictives illocutionary act, and the response of the audience is applause; the category of Applauding is part of Behabitives illocutionary act.

By comparing the result of the study with an independent rater, the data was reviewed. According to Arikunto (2014), co-researcher or co-rater was needed in avoiding the bias and subjectivity of the data. In order to find the coefficient agreement, the data from the co-rater was analyzed. The formula was used to find the agreement created by H.J.X. Fernandes and modified by Arikunto (2014). The formula can be seen below:

$$
\begin{aligned}
& K K=\frac{2 S}{N 1+N 2} \\
& \text { Notes: } \\
& \text { KK = Coefficient Agreement } \\
& \mathrm{S}=\text { Agreement Agreed } \\
& \mathrm{N} 1=\text { Total code made by Co-rater } 1 \\
& \mathrm{~N} 2=\text { Total code made by Co-rate } 2
\end{aligned}
$$

Silampari Bisa: Jurnal Penelitian Pendidikan Bahasa Indonesia, Daerah, dan Asing Vol. 4, No. 1, June 2021 
Robiah AL Adawiyah, Irma Diani, Azwandi

Illocutionary Acts Used in the Dead Poets Society Movie

Table 3. Strength of Agreement for Researcher \& Co-Researcher

\begin{tabular}{cc}
\hline $\begin{array}{c}\text { KK } \\
\text { (Coefficient Agreement) }\end{array}$ & Strength of Agreement \\
\hline $0.81-1.00$ & Very Good \\
\hline $0.61-0.80$ & Good \\
\hline $0.41-0.60$ & Moderate \\
\hline $0.21-0.40$ & Fair \\
\hline$<0.20$ & Poor \\
\hline & Source: Arikunto (2014)
\end{tabular}

The table above shows the data about strength of agreement between the researcher and the co-researcher. From the result of the agreement $(\mathrm{KK})$, this table was used as a guide to assess the degree of agreement. The strength of the 'Moderate' agreement was the minimum agreement that the researcher and coresearcher had to reach. To avoid the researcher's subjectivity, this agreement intensity was entirely required.

\section{Results and Discussion}

1. Results

The result of the data analysis is taken from the analysis process through the speech acts on data that is identified and evaluated according to the theories in the Dead Poets Society movie script. This part explains the findings of the research regarding the types of illocutionary acts found in Dead Poets Society movie based on Austin's theory

a. The Categories of Illocutionary Acts Used by Characters in Dead Poets Society Movie

From the characters below, the findings of the research regarding the types of illocutionary acts found in Dead Poets Society movie based on Austin's theory. The following are some of the characters that will be revealed in the illocutionary act contained in the Dead Poets Society movie: Robin Williams as John Keating, Robert Sean Leonard as Neil Perry, Ethan Hawke as Todd Anderson, Josh Charles as Knox Overstreet, Gale Hansen as Charlie Dalton, Dylan Kussman as Richard Cameron, Allelon Ruggiero as Steven Meeks, James Waterston as Gerard Pitt. , Alexandra Powers as Chris Noel, Leon Pownall as George McAllister, Latin teacher, George Martin, Dr. Hager, mathematics teacher, Jane Moore as Mrs. Danburry, Kevin Cooney as Joe Danburry, Colin Irving as Chet Danburry, Matt Carel as Kurt Hopkins, John Cunnigham as Mr. Anderson, Lara Flynn Boyle as Ginny Danburry. The following are the results found from the amount of data that appears based on illocutionary acts contained in the movie scripts:

Table 4. Types of Illocutionary Act Used by the Character in Dead Poets Society Movie

\begin{tabular}{|c|c|c|c|}
\hline No. & $\begin{array}{c}\text { Type of } \\
\text { Illocutionary Act }\end{array}$ & Illocutionary Force & Percentage \\
\hline 1. & Verdictives & $\begin{array}{l}\text { Estimating (6) } \\
\text { Ruling (2) } \\
\text { Governing (1) } \\
\text { Describing (5) } \\
\text { Interpret (5) } \\
\text { Analyzing (2) } \\
\text { Calculating (1) }\end{array}$ & $30,55 \%$ \\
\hline
\end{tabular}

Silampari Bisa: Jurnal Penelitian Pendidikan Bahasa Indonesia, Daerah, dan Asing Vol. 4, No. 1, June 2021 
Robiah AL Adawiyah, Irma Diani, Azwandi

Illocutionary Acts Used in the Dead Poets Society Movie

\begin{tabular}{|c|c|c|c|}
\hline 2. & Exercitives & $\begin{array}{l}\text { Urging (5) } \\
\text { Advising (2) } \\
\text { Warning (3) } \\
\text { Choosing (1) }\end{array}$ & $11,38 \%$ \\
\hline 3. & Commissives & $\begin{array}{l}\text { Agreeing (2) } \\
\text { Purposing (2) } \\
\text { Promise (2) } \\
\text { Planning (1) }\end{array}$ & $7,38 \%$ \\
\hline 4. & Behabitives & $\begin{array}{l}\text { Complimenting (4) } \\
\text { Wishing (1) } \\
\text { Felicity (1) } \\
\text { Apologizing (3) } \\
\text { Congratulating (2) } \\
\text { Criticizing (2) } \\
\text { Welcoming (2) } \\
\text { Thanking (1) } \\
\text { Applauding (2) } \\
\text { Dare (1) }\end{array}$ & $18,77 \%$ \\
\hline 5. & Expositives & $\begin{array}{l}\text { Denying (3) } \\
\text { Mentioning (4) } \\
\text { Believing (2) } \\
\text { Reporting (1) } \\
\text { Asking (2) }\end{array}$ & $12,77 \%$ \\
\hline & Total & 72 & $100 \%$ \\
\hline
\end{tabular}

The table above shows that the characters perform most number of Verdictives which stands on the highest percentage 29,57\%. Meanwhile, Commissives has the lowest percentage, only $9,85 \%$.

b. The Interlocutors React to Illocutionary Forces Expressed by the Speakers in Dead Poets Society Movie

The more dominant types of interlocutors react to illocutionary forces expressed by the speakers in Dead Poets Society movie is Behabitives illocutionary act and Expositives illocutionary act. The most shown by the interlocutor is applauding and denying. The most shown by the interlocutor is applauding and denying. This movie presents a show of several characters who express their thoughts into a poem, then present it in public, so that the form of appreciation for this performance is by giving applause, besides that this form of denying mostly occurs when conflicts of contradiction arise between Neil and Mr. Perry, that is why these two things dominate in speech act reactions.

\section{c.Inter-Rater Reliability}

For both the researcher and co-researcher, this section shows the estimation of inter-rater reliability. For short knowledge, the co-rather was "DPS" who was a master's degree alumnus at Bengkulu University. In addition, she has conducted similar research from the film on the Study of Speech Act. Since she has expertise and experience in the study of speech acts, the co-rater has chosen it. The results can be represented in the following tables. 
Robiah AL Adawiyah, Irma Diani, Azwandi

Illocutionary Acts Used in the Dead Poets Society Movie

\begin{tabular}{cccc}
\hline \multirow{2}{*}{ Scrip Movie } & \multicolumn{2}{c}{ Agreement \& Disagreement } & \\
\cline { 2 - 3 } & Researcher & Co-Researcher & Note \\
\hline 1 & 1 & 1 & $K K=\frac{2 S}{N 1+N 2}$ \\
Total & 1 & 1 & $K K=\frac{2.1}{1+1}$ \\
& & & $K K=1$ \\
\hline
\end{tabular}

The researchers discovered the reliability of the data based on the tables above. Based on the data from the co-researcher, the reliability was also determined. The coefficient agreement for the category of culture material reached $\mathrm{KK}=1$ as a description of the data in Table 3. It can be described as an illocutionary act of a category; the researcher and co-researcher have the strongest agreement.

\section{Discussion}

Based on the data result above, was found in this analysis of the illocutionary act. The movie was entitled Dead Poets Society is the object of the research. It is one of the greatest movies ever made internationally. There are several categories won by the Dead Poets Society. It shows you how the concept of schooling was out of the question. To those who still apply the old way of teaching and learning, the plot of this film seems like a parody. This movie may be a good educational guide. The storyline of this movie teaches how to teach in a different way from another teacher, the technique of using students' imaginations to make them creative so that this method seems not boring, and some of them can easily understand the content of the material with different teaching methods.

First, The researcher found 72 utterances illocutionary acts from the movie. The more dominant categories of illocutionary acts used by characters in the film Dead Poets Society are Verdictives, and Behabitives. It means that from the film there are many expressions of part of an act of "Estimating" especially "Estimating the time" all forms of conversation related to estimation are categories of the Estimating speech act section found in Verdictives illocutionary act. Whereas the second speech act that often appears is in the form of "complimenting", this means that it is also often found in the Dead Poets Society films. The researcher assumes that because of the genre of the film, the explanation for the styles is more prominent, so why the characters demonstrate the use of estimating, explaining, interpreting, and complimenting.

Second, the more dominant types of interlocutors react to illocutionary forces expressed by the speakers in Dead Poets Society movie is Behabitives illocutionary act and Expositives illocutionary act. The most shown by the interlocutor is applauding and denying. The most shown by the interlocutor is applauding and denying. This movie presents a show of several characters who express their thoughts into a poem, then present it in public, so that the form of appreciation for this performance is by giving applause, besides that this form of denying mostly occurs when conflicts of contradiction arise between Neil and Mr. Perry, that is why these two things dominate in speech act reactions. 
Robiah AL Adawiyah, Irma Diani, Azwandi

Illocutionary Acts Used in the Dead Poets Society Movie

There are some illocutionary acts performed by speakers and fall into the illocutionary category but there are no reactions performed by the speakers, for example in the section below:

Keating : Just when you think you know something; you have to look at it in another way. Even though it may seem silly or wrong, you must try! Now, when you read, don't just consider what the author thinks. Consider what you think."

Keating : :Boys, you must strive to find your own voice. Because the longer you wait to begin, the less likely you are to find it at all. Thoreau said, "Most men lead lives of quiet desperation." Don't be resigned to that. Break out!"

Keating notices Spaz and another boy leaving the desk immediately.

Keating : "Don't just walk off the edge like lemmings. Look around you."

$(A D / 00.43 .31)$

From some of the dialogues above, the expressions conveyed by Keating contain advice for his students while in the class; it can be found that the category of expressions conveyed by Keating is a form of Advising in Exercitives in illocutionary act. In the dialogue above, there is no reaction to illocutionary forces expressed by the speakers. Therefore the classification drawn based on the movie dialogue may not be generalizable and calculate $\mathrm{d}$. The scope of the problem was only focused on illocutionary act used by characters and interlocutors react so that there is some act did not found and listed into category of illocutionary act. Data not found in the categories of illocutionary acts used by character in Dead Poets Society based on Austin's theory are as follows.

In Verdictives illocutionary act is evaluating; in Exercitives illocutionary act are appointing and voting; in Commisives illocutionary act are declaration and announcement; and in Expositives illocutionary act is understanding. While Data not found in the interlocutors react to illocutionary forces expressed by the speaker in Dead Poets Society movie based on Austin's theory are as follows: in Verdictives illocutionary act are ruling, governing, and evaluating; in Exercitives illocutionary act are appointing and Voting; in Commisives illocutionary act are declaration, announcement, and opposing; in Behabitives illocutionary act are wishing, felicity, criticizing, and dare; Expositives illcutionary act is reporting.

The genre of this film is comedy and drama. The scenes that appear are mostly about drama, both between parents and children, teachers and students, the conflicts that arise are everything that is against the four pillars of this school, their children's desires that conflict with their parents make conflicts often appear, this movie is dominated by the location of the scene, namely the Welton Academy school, so that when classified according to the illocutionary category based on Austin's theory many dialogues and conversations that reveal about interpretation, analyze, and compliment.

\section{Conclusion}

First, the researcher discovered in this study all kinds of categories of speech acts based on the Austin's theory, they are verdictives, exercitives, commisives, behabitives, and expositives. Second, the more dominant categories of illocutionary acts used by characters in the film Dead Poets Society are $29,57 \%$ Verdictives illocutionary act and $26,75 \%$ Behabitives illocutionary act. The researcher assumes 
that because of the genre of the film, the explanation for the styles is more prominent, so why the characters demonstrate the use of estimating, explaining, interpreting, and complimenting.

Third, the more dominant types of interlocutors react to illocutionary forces expressed by the speakers in the Dead Poets Society movie is part of Behabitives illocutionary act and part Expositives illocutionary act. The most shown by the interlocutor is applauding and denying. This movie presents a show of several characters who express their thoughts into a poem, then present it in public, so that the form of appreciation for this performance is by giving applause, besides that this form of denying mostly occurs when conflicts of contradiction arise between Neil and Mr. Perry, that is why these two things dominate in speech act reactions. The researcher hopefully, this research can be used as a reference in studying speech acts in pragmatics because, in this study, the researcher classified the types of illocutionary acts more easily and understanding based on Austin's theory.

\section{References}

Afghari, A. (2007). A sociopragmatic study of apology speech act realization patterns in Persian. Speech Communication, 49(3), 177-185. doi:10.1016/j.specom.2007.01.003

Arikunto, S. (2014). Prosedur penelitian suatu pendekatan praktik. Jakarta: Rineka Cipta.

Austin, J. L. (1962). How to do things with words. Oxford: Oxford Univesity Press.

Faradila, R. \& Hamzah. (2013).The use of illocutionary act in movie "The blind side". English Language and Literature, 1(1), 174-184, http://ejournal.unp.ac.id/index.php/ell/article/view/2408

Horn, L. \& Ward, G. (2006). The Handbook of Pragmatics. United Kindom: Blackwell.

Leech, G. (1991). Principle of pragmatics. Longman Singapore Publisher: Singapore.

Maryam, D. (2020). Deletion pada penerjemahan directive speech act film the maze runner. Deskripsi Bahasa, 3(1), 47-56. doi:10.22146/db.v3i1.400

Mey, L. J. (2001). Pragmatics an Introduction second edition. Australia: Blackwell Publishing.

Noermanzah, N. (2019). Bahasa sebagai alat komunikasi, citra pikiran, dan kepribadian. Seminar Nasional Pendidikan Bahasa dan Sastra, Prosiding Seminar Nasional Bulan Bahasa (Semiba), 307, https://ejournal.unib.ac.id/index.php/semiba/article/view/11151/5537 
Parker, F. (1986). Linguistics for non-linguists. London: Taylor \& Francis, Ltd.

Putra, P.W.H. (2017). A study of Mr. Keating's speech act In Dead Poet's Society movie. Bachelor Degree, University of Muhammadiyah Surakarta. Retrieved from https://repository.usd.ac.id/22966/2/121214142_full.pdf

Sania, D.S. (2018). An analysis of illocutionary acts used in Titanic movie. Bengkulu: Universitas Negeri Bengkulu.

Searle, J. R. (1979). Expression and meaning: Studies in the theory of speech act. Cambridge: Cambridge University Press.

Syafryadin, Dian, E. C. Wardhana., Eka Apriani., \& Noermanzah. (2020). Maxim variation, conventional, and particularized implicature on students' conversation. International Journal of Scientific and Technology Research, 9(2) https://doi.org/10.31219/osf.io/cza8y.

Wray, A. \& Bloomer, A. (2006). Projects in linguistics. United Kingdom: Oxford University Press.

Yule, G. (1996). Pragmatics. Lousiana: Lousiana State University. 